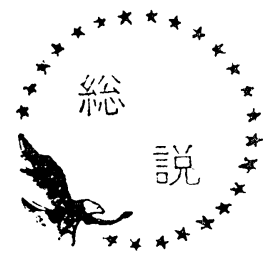

I . 緒讋

わが国に扔ける石炭生産量は年間 5,000 万 $\mathrm{t}$ 程度に 達しており，今なおェネルギー消費全体の相当な部分 を占めている。にもかかわらず, 石油, 天然ガスの発 展および原子力の開発は, 石炭産業の世界的な斜陽化 をもたらしつつあるが，この際いたずらに悲壮感に落 ちいることなく, 石炭を単なる燃料として利用するだ けにとどまらず, 貴重な有機質固体として, また重要 なカーボン資源として, 新しい石炭の利用分野を開拓 する必要がある。このためにはじつくりと腰をすえ て, 石炭科学の基礎的研究を推進し, 石炭の持つ化学 構造に由来する物理化学的性質を明らかにする必要が 西る。特に外国炭と地質年代を異にする日本炭の化学 構造, 基礎的性質を明確にし, 外国炭との相異点を確 実につかむことによつてこそ，日本炭の持つ特性を活 用した新利用技術の開発が，図られてくるものと信ず る。

これらについて一例をあげて考えてみると，最近， わが国に㧍ける製鉄業の急伸に伴なら原料炭対策の一 環として, 国内炭利用のための予熱炭装入法, 成型炭 装入法, 熱間成型炭乾留法などいくつもの技術開発が 進められており，この中にはすでに試験検討の段階を 終えたものもある。また大気污染防止対策として無煙 燃料を目標とした無煙ブリケットの開発，活性炭ある いは電極材などカーボン材料としての利用開発が進め られつつある。これらのうちには，石炭自身が有する 熱可塑性を利用してバインダーなしで成型する方法, また熱処理初期段階における熱分解機構の挙動が，そ れ以後における加熱，炭化に拉よぼす効果など，いく つもの石炭の基礎的物性の特徵が生かされており, 石 炭の基礎的性質解明の必要性を示寸ものである。

一方, 諸外国に扔いても，イギリスの B. C. U.R. A., B.C.R.A., アメリカの Bureau of Mines, カ ナダのアルバータ州立研究所, ドイッのエッセン中央 石炭研究所, フランスの C.E.R.C.H.A.R., オラン ダの国立石炭研究所, 㴚州の C.S.I.R.O.など多く
燃料協会石炭科学部会長 本 田 英 昌 資源技術試験所 木 村 英 雄

の研究所が，自国に産出する石炭の基碟研究を鋭意進 めており，关れぞれ国情に則した利用開発について検 討している。アメリカの石炭研究局(O. C. R.) による 高発熱量ガス, ジェット燃料の製造, スラリ一輸送, チヤーの利用, 超微粉炭の開発研究なども, これらの 一つの行き方を示すものとして注目されるところであ る。

一口に石炭科学といっても, 石炭の生成から採掘, 選炭，利用に至るまで，あらゆる分野にわたる基礎的 問題を包含しており，これらに対する理論的，技術的 考察は，かならずや石炭利用工業に詨しても大いなる 貢献をするものと思考される。さらに, これらの各分 野における研究者の横の連絡を図り，それぞれの専門 的見解に立つた論議を行ならことも, これからの石炭 科学を発展させるらえに重要な問題である。

この間にあつて, 燃料協会内に石炭科学部会が設置 され, 各専門分野間の横の連携を図りつつ, 石炭科学 の発展を期していることは，意義深いものがあるとい わなければならない。

本稿は紙面の都合で，多方面にわたる石炭科学のあ らゆる分野について，その多くを充分に述べることは 不可能と思われるし, また研究の総括も著書, 石炭・ 石炭化学 ${ }^{1)}$ に網羅されているので, ここでは, わが国 における最近の現状を主とした石炭科学部会および研 究動向について, 石炭の生成, 石炭組織, 物理的性 質, 化学的性質, 熱分解などの各項目について, 基礎 研究の必要性を痛感しつつ大観してみることにする。

\section{II. 石炭の生成}

現在そこにある炭田が，どのようにしてそこに植物 を堆積し炭層を形成するに至つたか，またその時の堆 積盆地の状況は，植物の集積は，気候はどうであつた かは, 炭田の規模, 石炭の性状を考察する上任重要な ことである。さらに, 炭層生成後における地壳の変 動火山活動など種々の 2 次的, 附加的変動の影響がど らであつたかは，前者の場合以上に，石炭に幾多の変 成の幅をもたらす結果とさえなつている。 
これらの炭田の生成に関連した問題は，興味があり 多くの植物学者, 地質学者によつて埨議が繰り这えさ れているところであり，時には物理的，化学的な立坋 にある者からも相互に検討が加えられている。

植物の立場からでは, 古植物の樹種の沠定, その当 時の気候の判定, それらから発展した植生環境あるい は炭田生成の推定を行な抢らとしている。一例をみる と, 亘理 ${ }^{2)}$ は九州地区における炭層中の松岩について の研究から,この地区の炭層は主として松岩のような 針葉樹が多いので，炭層生成の主材を供給した植物は 針葉樹であると思われること，炭層以外の地層中には 広葉樹を多く認め, しかも樹種加らって温暖あるい は亜熱带性気候が考えられること，松岩の分布状態か らその場所に堆積した之思わ机ることなどを示してい る。

いずれにしても，岸廨生成当時における樹種は，現 在われわ机が見るところとほとんど大差はないが，父 候は現在よりも，より温暖であつたことが想像される。 一方, 徳永 ${ }^{3}$ 以炭層中の花粉分析の結果から, わが 国における炭田の樹種を明らかにしている。これは石 炭中で花粉が多量に含まれているドリット部分をと り, $\mathrm{HNO}_{3}$ および $\mathrm{KOH}$ 処理するもので, 花粉類は 残渣中に残る。この結果，わが国に扮ける古第三紀炭 では，広葉樹を主としこれに針葉樹，単子葉植物をま じえているが，新第三紀炭では針葉樹を主とし広葉樹 をまじえていることなどが認めら机ている。またわが 国でも，炭層中にウラン鈗物の存在が認められる新潟 県赤谷, 宮城県大内の石炭中の花粉についても調查 中²) である。

炭田の生成に関しては, 佐々 ${ }^{4)}$ が石狩炭田を主とし て総括的な論議を下している。すなわち石狩炭田にお ける植物の准積は, 比較的平静な時期に行なわれ, そ の准積盆地も緩除な沈降運動であつて, 時に冠水, 時 に植物の繁茂といつた輪廻層を形成するような運動を 伴なつたもので, 樹種は温帯性樹林を主とし, これに 暖帯性樹林をまじえており, 気候としては現在の沖繩 地方に近似した状態にあつたものと推察している。さ らに石炭組織分析から堆積盆地の動きほ, 石炭組織の 構成に, 結局は炭質にも関連してくることを示してい る。

炭田の生成を単に地質学的な立場に立つてのみ考察 するだけではなく, 花粉分析, 組織分析, 工業分析な どを附加して考えるようになつてきつつあることは， この方面の今後の発展にプラスされるところが多いも のと思考される。それにしても，炭質に差異が生ずる

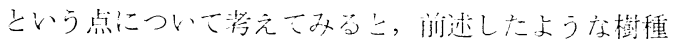

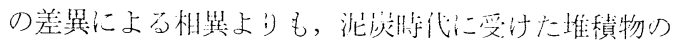

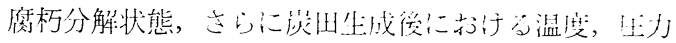
なざが影響した二次的な恋成段倩りはが，淡筫に刘 して大きく影響するもいと想われる。この点関した

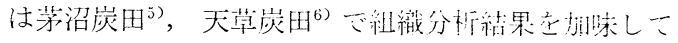
考察を加えた例からみ下も，关の一端在うかがうこ二 ができる。同様の考え方から，最近 H. J. Kisch ら”

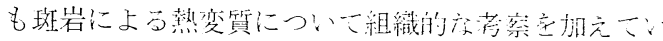
る。また炭層中の花粉の将察方ら, 炭田生成の温度, 圧力などが推定できるならば，石岸化につ、一の新た

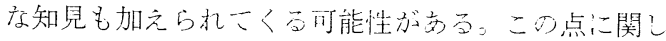
ては，D. Chandra”゙が的率測定上り熱变成岸の生 成温度条件につ心下の推定在行度つ下いる。

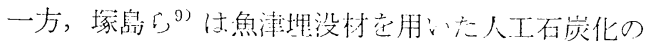
研究を行ない，不炭の根源物筫上しー法リグニンもセ

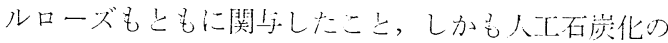
初期現象は天然不炭化上变わらないこ上な上明らか にし, 北海道低石炭化度炭の人工石岑化についたも D W. van Krevelen の構造解析䘮加えて闹様の結果 ${ }^{9}$ を 得ている。このセルローズ説は, 古くは F. Bergius が示し，が国ではこの方面に精力的な研究长進动た 舟厉，横川103らによつて結諭されたセルローズ説とも 一致するものである。

最後に, 炭田の生成問題に関連して注目されること は，的が国の炭田事情から，来た製鉄用炭碓保の意味 から，これを海外の輸大に仰いでいるが，さらに一歩 進めて海外の炭田に直接投資し開発しょうとする気運 が見受けられる。このためにアラスカ，カナダ，アメ リカ, 濠州, 東南アジアなどいくつもの海外飞おける

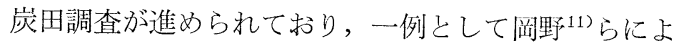
り濠州クインスランド州東部炭田の調查状況が報告さ れている。

\section{III. 石 炭 組 織}

石炭組織に関する研究が急速に発展したのは戦後で あるが，現在では石炭組織そのものの分類基準をどう するかという問題, 一方では石炭組織と他の物性ある いは化学構造との関係などの問題に対して向けられて いる。

分類基準に関しては,わが国に打ける石炭組織研究 者の集りである燃料協会内の石炭組織研究グループ が, 討議し合い, 石炭の堆積環境というか堆積物の腐 杯分解が行なわ机たいわゆる泥炭化時代における環境 をも考慮に人れた考え方文加味して，基貿がビトリニ ットであるかデグラデイニットであるか上いうこ上を 


\section{第 1 表 石炭組織成分分類 の比較}

\begin{tabular}{|c|c|c|}
\hline 日 & 本 & 英 \\
\hline 輝 & 炭 & $\begin{array}{l}\text { ビトレーン } \\
ク ラ レ ー ン\end{array}$ \\
\hline 暗 & 岸 & ジュレーン \\
\hline
\end{tabular}

炭質貝岩岸質貢岩

木質炭甘

顕微鏡的な分類 (microlithotype)

$$
\begin{aligned}
& \text { 国際学会の分類(1957年) } \\
& \text { ビトリット } \\
& \text { クラリット } \\
& \text { ドトット } \\
& \left(\begin{array}{l}
\text { ドリット } \mathrm{E} \\
\text { ドリット } \mathrm{I}
\end{array}\right)
\end{aligned}
$$

カルバルジリット あるいは炭質頁岩

フジット

$$
\begin{aligned}
& \text { 日本炭り分類 (1958年) } \\
& \text { ビトリット } \\
& \text { クラリット } \\
& \text { ドリット\{ }\left\{\begin{array}{l}
\text { エシニット・ドリット } \\
\text { イナーチニット・ドリット } \\
\text { ミネル・ドリット }
\end{array}\right.
\end{aligned}
$$

炭質真岩

フ ジッ ト
基礎とした日本炭のための分類基準を制定するに至 り，これを本誌上 ${ }^{12}$ に発表している。ちなみに，この 分類基準を国際分類と比較して示すと第 1 表 $^{13)}$ のちお りである。

この分類制定に当つて生れたデグラデイニットおよ びエクジニット・ドリットの名称は，すでに国際石炭 組織命名委員会が発刊した石炭組織のための辞典 ${ }^{14)}$ も掲載されている。しかしながら，石炭組織に対する 分類は，国際間でもしばしば問題となつているところ で，これは石炭の生成環境を考えれば，また石炭が有 機質の固体であることを考えれば当然のことといわな ければならない。従つて最近では1965年10月ハンガリ 一のブタペストで第18回命名法委員会が，続いて第19 回が昨年10月にスペインのマドリィドで開催されてい るような状洗である。わが国にも昨年の同委員会座長 であつた濠州 C.S.I.R.O. の G.H. Taylor より, 分類案についての意見および国際学会への石炭組織研 究者の名簿作成のための登録希望がよせられたので, 燃料協会を通じて送附してある。

さてこの会議の資料を通覧して考えられることは, 石炭組織がより細分化される方向に向つていること， 新しい用語を用いるような，あるいは加えるよらな提 案がなされていること, 従来の瀝青炭のための分類に 加えて褐炭のための分類基準にも力を入れていること などであるが，この諸点についてはいくつかの問題が 残されるように思われる。

一方，わが国においても，このような動きを示して いる国際分類との比較において, 現状のままでよいの か，よりよい日本炭に適した分類を打立てるべきか， あるいは国際分類をそのまま適用すべきか，一部修正 して適用するかなどといつた問題があり，この辺はさ らに討論を重ねて決定されなければならない重要な問 題である。いずれにしても，日本炭と外国炭との間に
イナーチニット，デグラディニットなどの組織構成上 に特徴的な差異が存すること，また混在する粘土鉱物 の取り扱い方をどらするか，日本炭を瀝青炭としての 分類にするか, 一部褐炭の分類に入れるかなど堆積環 境をも含めて, 日本炭のための, あるいは第三紀炭と もいえるであろうが，石炭組織分類基準を適切に確立 する必要がある。

わが国における炭田あるいは炭層の石炭組織の特徵 は, 木村 ${ }^{15)}$, 佐々 ${ }^{16)}$, 高橋 ${ }^{17)}$, 柴岡 ${ }^{18)}$, 中柳 ${ }^{19)} ら に$ よつて遂次明らかにされつつある。

組織成分に関連づけた石炭の物理化学的性質に関し ては, 総合的には岩崎 ${ }^{20)}$ の研究があるが，最近では反

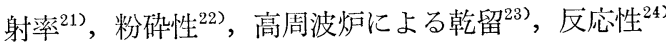
などに関する研究がみられる。また内外コークス用炭 の微細組織成分の特徵 ${ }^{25)}$ を明らかにしたもの, 電子顕

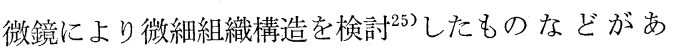
る。すなわち木村らは, 日本のコークス用炭の微細組 織成分は，ビトリニット，デグラディニットに富み， エクジニットが多く，イナーチニットが少ない特徴が あるのに対して, 外国炭ではビトリニットに富みイナ 一チニットも多い特徵があること, しかも C \% が増 加するに従いビトリニットが増加し， C $91 \%$ (daf) で エクジニットがほとん認どめられなくなることなどを 示している。また電子顕微鏡によると, 石炭の微細構 造は非常に均質な部分とそうでない部分とがあり，光 学顕微鏡よりもさらに多くの複雑な微細構造を呈する ことを認めている。

一方, 外国においては, 組織成分あるいは微細組織 成分の分離が比重の差異によつて比較的容易に行なえ るので, C. Kröger ${ }^{26)}$ を始めとして，P. H. Given 27), M. M. Roy ${ }^{28)}$ らよつて, 多くの系統的な物理 化学的性質が追求されている。

石炭組織分析法として K. Kötter ${ }^{29)}$ にり 20 点測 
定法が紹介されるや，この分析法の再現性がよいこ と，測定が比較的容易であることなどの理由により広 く利用されるようになつたが，日本炭も意外に多くビ トリニットが存在することが示されている。従つて20 点測定法により, 日本炭における組織上の特微がさら に明らかにされてくるものと思われる。

さらに, 最近における一つの特徴としては, 石炭化 あるいは石炭の本質を物理化学的に追求しようとする 場合, 前述したように岑田の生成上, 不炭の多様性の 故に, 比較的监純で，乙かも無機物の少ない組織成分 としてビトリットあるいは微細組織成分であるビトリ ニットを，その石炭の代表として取り扱う基礎的研究 が進められるようになつてきた。一例として現在資源 技術試験所, 早稲田大学, 石炭技術研究所の間で 500 ${ }^{\circ} \mathrm{C}$ までの熱処理炭（ビトリッ卜部分）を対象とした 熱処理効果の解明 ${ }^{30)}$ が行なわれているが，乙机恃石炭 研究の一つの大きな発展であるといえよう。

このように，従来よりもより純率に近い形の石炭に 対して種々の物性解析機器を駆使できることは, より 比較検討し易いデータが生れてくるものと思われ，今 後の発展が期待されるところである。

石炭組織の分離に関する研究として, 比重分離がし ばしば検討されてきたが, 注目される研究の一つとし て, 向井ら ${ }^{31)}$ が Huff 式静電選鉱装置を用いてコロナ 放電を行ない，ビトリットおよびドリットをきわめて 能率よく分離する研究を進めて抢り, さらに湿塺の影 響として, 試料が加熱乾燥された状態よりも, 大気中 の相対湿度が 40 80\% のほうが分離効果がよいこと を認めている。この方法は, 石炭組織に即态した有効 利用への一環として考える時興味ある研究である。

\section{IV. 石炭の物理的性質}

近年における核磁気共鳴吸収 (NMR), 電子スピン 共鳴吸収 (ESR), 赤外拄よび紫外吸収, 質量分析, ガスクロマトグラフなどの測定機器, 分析機器の発展 は目覚しいものがあり, これらの機器を利用した石炭 の性状，構造に関する新しい知見，手掛りを得ようと する努力が，ますます目立つようになつてきた。そし てこれらの中にはいくつかの興味ある結果も得られて いる。つぎに最近にみられる報告を中心として, 石炭 の物理的性質についてみてみよう。

\section{1. 機械的性質}

石炭の機械的性質に関連した問題として, 微小硬度 の測定が行なわれている。紫波ら ${ }^{32}$ は 200 500 $\mathrm{C}$ ま での熱処理炭のビトリット部分のヌーブ硬度を測定 し, 石炭化度之加熱初期段階における硬度の変化につ

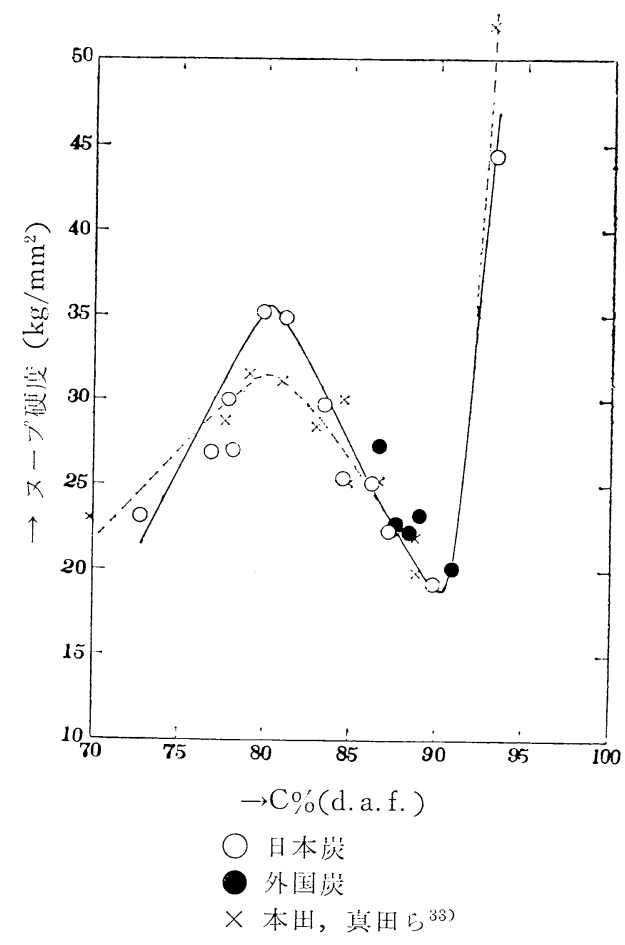

第1図 ヌープ強度と石炭化度との関係

いて検討したが，第1図のように石炭が C $80 \%$ で一 端極大值となるが，また C $90 \%$ 附近で極小值とな り，それからは急上昇するといら結果を得ている。こ れは本田, 真田 $5^{33}$ また D. W. van Krevelen ${ }^{34)} の$ 結果ともよい一致を示している。この場合, 石炭化度 の低いところで硬度の極大值が存在することに対して 考察した結果, 石炭の含酸素基は一般に石炭化度の増 大とともに減少する傾向が認められるが，この附近に おいては 一- O- 型の酸素が逆に増大寸ることから酸素 架橋構造が発達するためであることを推論している。 さらに熱処理炭についてみると, 日本炭と外国炭との 差異はほとんど認められないこと, 極小值を示す処理 温度は石炭化度が増大するとともに高温側にずれるこ となどを認めている。

一方, 資源試においては, 加熱微小硬度計による熱 間の微小硬度の変化について考察が進められている が, これらの結果は, 石炭の内部結合力, 可塑性に関 する知見が得られるので今後の発展が期待される。

さらに Hordgrove 粉砕性試験装置により, 石炭化 度の異なる石炭が粉砕性の差異におよぼす石炭組織の 影響，石炭中に存在する結晶性鈆物の影響などについ

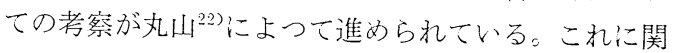


連して，石炭を超微粉础 $(-32 \mu)$ して空気輸送しよ らとする考え方から, 本間 ${ }^{35}$ らは超微粉炭の内部摩擦 角, 流れ曲線, 流動度, 降状值などの流動性に関する 研究を進めている。

これは赤平で現地試験が行なわれた石炭のスラリー 輸送と同様に, 石炭を一つの流動粉体として輸送し利 用しようとするもので，さらにこれに加えて微粉确化 による脱灰, 脱硫效果をもか数て扔り, 超微粉炭の利用 開発とともに今後の問題として興味深いものがある。

2. 真比重, 内部表面積

石炭の真比重を求めることは, 石炭化度との関係を 知る他に石炭の内部構造解析上重要な知見が得られる ので, 最近特に多くの世界各国の研究者によつて盛ん に検討されており，このために数多くの報告がみられ る。真比重を測定する場合, なにを置換物質として用 いるのがよいかといら点に関しては，種々議論がつき ないところである。ところでメタノール，水などを置 換物質とした場合，これらは分子量が大きく，膨潤が 起る，極性があるなどの理由により，真比重をよく表 わせないのではないかといわれており，現在ではへリ ウム（分子直径 $2 \AA$ ）を用いるのが，もつとも信頼性 が苚いとされている。J. A. Dulhunty ら ${ }^{36)}$ おるび P. Zwietering, D. W. van Krevelen $5^{37)}$ は, ヘリ ウムによる真比重を求め, C $85 \%$ 附近に極小值があ るが，これより高石炭化度になると急激に大きくな り，石墨の比重 (2.25) に近づくといらことを示して いる。日本炭でも C $85 \%$ で極小值を示すことは，水 による測定で本田ら ${ }^{38}$ が，メタノールにより太刀川 ${ }^{399}$ がそれぞれ報告している。へリウムによる真比重測定

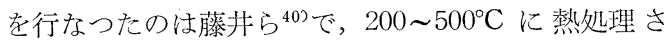
れた石炭化度の異なるビトリット部分について測定 し，三池炭クラスの C $85 \%$ 附近で極小値となり，石 炭化度の增大とともに増加すること, しかも第 2 図の 上うに真比重の逆数はその水素含有量に関係があり,

日本炭，外国炭ともに同一曲線上にのることを明らか にした。さらに D. W. van Krevelen のグラフ法に より芳香族炭素の割合 $f_{a}$ を求めたところ, 原炭, 熱 処理炭ともに $f_{a}$ と $\mathrm{H} / \mathrm{C}$ 原子数比との関係が, 同一 曲線上にのること，外国炭も同様であることなどを認 めている。なお，水素含有量と直線関係があるものと して, D. Chandra ${ }^{41)}$ が,ニュージランド炭のビトリ ットの反射率についても認めている。

石炭の内部表面積もまた真比重とともに, 石炭の微 細空隙扔よび毛細管構造を解析する上に重要である が, やほり吸着剤の問題が注目の的となつている。従

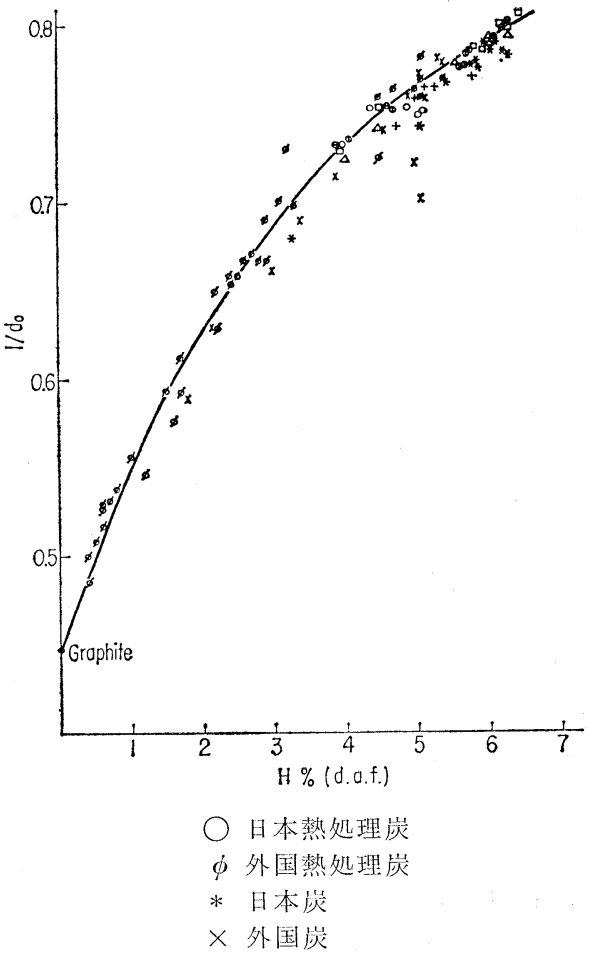

第 2 図 $1 / \boldsymbol{d}_{0}$ と $\mathbf{H} \%$ との関係

来, Gregg 法, BET 法, 湿潤熱法いずれでも, 主と してメタノールが使用されていたが，前述したよらな 理由から，アルゴン，窒素などの不活性ガスを使用す る研究がなされている。しかし最近では $\mathrm{CO}_{2}$ が用い られ始め R. B. Anderson ら ${ }^{42)}$, P. L. Walker ${ }^{43}$ によつて, 石炭への適用性が检討されている。特に P. L. Walker は $298^{\circ} \mathrm{K} の \mathrm{CO}_{2}$ 吸着法が最適の方 法であることを認め, 表面積の值として 104 224 $\mathrm{m}^{2} /$ g を出している。

わが国でも太刀川 ${ }^{39}$ は, メタノールによる湿潤熱法 により石炭化度と内部表面積との関係を求めC $90 \%$ に極小值があることを認めている。また現在, 石炭化 度の異なる石炭㧍よびその熱処理炭に刘して, $\mathrm{CO}_{2}$ を 吸着剂とした BET 法による内部表面積が測定され, メタノール, 窒素との比較, 固有水分との関係などの 検討が進められている。一般に, 内部表面積は $\mathrm{CO}_{2}$ による值がもつとも大きく，ついでメタノール，窒素 の順となつており，石炭に対する信頼度を高く評価す るむきもあるが, 活性炭, カーボンに対しては $\mathrm{N}_{2} \geqq$ $\mathrm{CO}_{2}$ の場合もあることが示されており ${ }^{41)}$, 議論はま だ充分にしつくされていない状態にある。

なお，この問題に関連させて考えると, 今泉ら ${ }^{45)}$ は 
石炭の浮選特性を浮選動力学的な立荕加ら解析してい るが, 浮選性は石炭の比重, 粒度, 不埮化度に相関性 があることを認めており，特に浮選速度定数が C 85 \% 附近で極小值となることを示している。

以上のように, 真比重, 内部表面積, 浮選速度走数 が，いずれも C $85 \%$ 附近で一つの転移点を示すこと は，石炭の構造解析上注目すべきことである。

\section{3. 赤外吸收スペクトル}

石炭の化学構造解明のために, 石炭化度の異なる石 炭に対して KBr 法に上る測定が, 武谷ら ${ }^{46)}$, 藤井ら 47)によつて行なわれている。武谷らは, 北淛道炭り含 酸素基について測定し, 活性含酸素基 $(\mathrm{OH}, \mathrm{C}=\mathrm{O}$, $\mathrm{COOH})$ は，いずれも石篇化度が增大すするともに減 少すること，エーテル結全その他の不活性含酸狋基以 C 80\% 附近に極小值があることなどを認めている。

一方藤井らは $3.40 \mu$ における吸収㡀は脂肪族 CH によるものであるが，これは C 84.5\% 附近で極大值 をとり，それ以後は急速に減少寸る。来た $6.25 \mu$ に おける異常に强い吸收带の州属については，しばしば R. A. Friedel $5^{48)}$, G. Bergmann $ら^{49)}$ につて諭 議されていたところであるが， $\mathrm{LiAlH}_{4}$ による還元あ るいはジアゾメタンおよびジメチル硫酸によるメチル 化した石炭との比較から，石炭中に水素結合したカル ボニル基が存在していることが，一つの原因となつて いることを認め，R. A. Friedel らの意見と同様であ ることを結論している。

いずれにしても，赤外吸収スペクトルにより，石炭 中には $\mathrm{OH}$, 芳香族および脂肪族 $\mathrm{CH}, \mathrm{C}=\mathrm{O}, \mathrm{CH}_{2}$, $\mathrm{CH}_{3}, \mathrm{C}-\mathrm{O}, \mathrm{C}-\mathrm{O}-\mathrm{C}$ および縮合芳香族核などが 存在することが認められるわけで, 石炭化度の発達と ともに,これらのうちの脂肪族側鎖または脂環構造が 次第に芳香族構造に変化していくものと考えられる。 しかも C 85\% 附近で脂肪族 CH が急速に減少する ことから，この辺から次第に芳香族構造を形成するよ らな素地が整えられるものと推察される。

4. 核磁気共鳴吸収スペクトル

石炭に刘して NMR が導入されたのは，ごく近年 のことで R. A. Friedel ${ }^{50)}$ によるが，わが国におい ていち早くこの分析法老採用して, 石炭の化学構造解 析に着手したのは武谷ら ${ }^{51}$ である。すなわち, 石炭の ピリジン抽出物を重水案ピリジンを溶媒として高分解 能 NMR による測定を行ない, 石炭の構造を形成す る各種結合様式のプロトンの含有量と元素分析值によ つて得られた石炭の構造パラメーターとの関連を求 め, 石炭の化学構造について解析している。これによ
ると, 夕張炭抽出物の平均的な構造勧位は, 約 4 環の 芳香族綰合環構造加ら構成されており，この步香族環

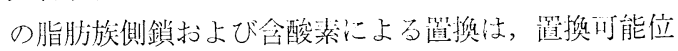
置総数の約 4 制艺上るていること，末た脂肪族倒鎖の 炭素㑑数は平均して 3 個となつていることなどが垫め られている。

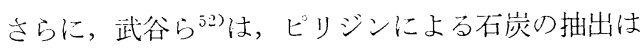
离灾 20\% 前後であるのに対して, キノリンにより石 炭の熱分解温度附近で抽出する上，きわ的下多量の抽 出物が待られることから, 夕张炭圭温度 $300 \sim 400^{\circ} \mathrm{C}$ で分解抽出を行ない，さらにピリジンで軍温抽出した ものについて, 重水桌ヒリジン在溶媒しして NMR スペクトルの测定老行なつた。このようにして来的ら

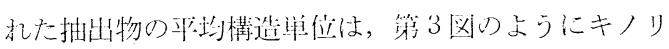
ン抽出の際の抽出温棉の上早に伴なつて抽出收率が堌 加与るが，この增加と一致して考香族性 $f_{0}$ 。が次第に 增加寸ること，またこの際の芳香族はわずかながら瓄

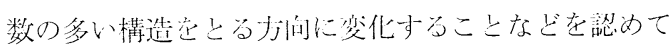

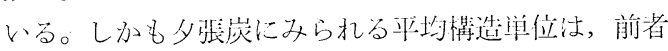
のピリジン抽出の場合でも, 後者のキノリンーーピリ ジン抽出の場合でも，あまり大差がないことが示され ている。

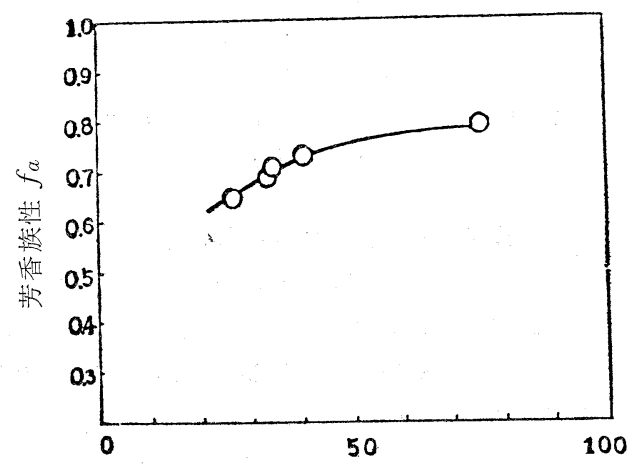

ピリジン抽出率（\%乾炭）

\section{第 3 図 ピリジン抽出率と芳香族性 $\boldsymbol{f}_{a}$ との関係}

5. 電子スピン共鳴吸収スペクトル

石炭の ESR に関する研究は 1954年 J. Uebersfeld ら ${ }^{53)}$ によつて始められたが，わが国では1955年横沢ら 54) が，夕張炭怙よび，そのピリジン抽出物について測 定している。その後いくつかの報告が内外にみられる が，最近では豊田ら ${ }^{55)}$ が不炭化度を異にする日本炭お よび外国炭のビトリット部分について真空中で測定を 行ない, ピーク間ライン幅, ライン幅, $g$ 值, スピン 濃度および緩和時間上石炭化度さの関係について検討 
している。この結果によると, 日本炭に対しては 1 成 分よりなる ESR シグナルが得られるが，C87.6〜 $90.7 \%$ の外国炭については，少なくとも 2 成分より なると考えられるシグナルが得られるといら興味ある 結果を認めている。すなわちピーク間ライン幅は, 広 い幅の成分と狭い幅の成分とが重なり合つているもの と推察されている。さらに第 4 図のように，ピーク間 ライン幅は, C $90 \%$ 附近までほとんど一定で 8 ガウ 久程度であるが, 石炭化度がさらに増大寸ると急激に 減少する傾向があること, 一方狭い幅の成分は約 1 ガ ウス程度で, 石炭化度とは関係なく一定值を示すこと などを認めている。

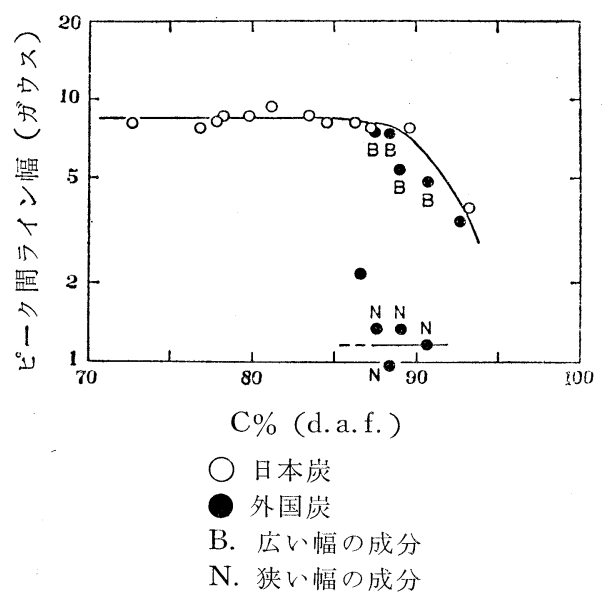

第 4 図 ピーク間ライン幅と石炭化度と の関係（真空中）

この他, 標準物質に対して比較検討寸るために，フ ェノール，3メチルフェノール，3.5 ヂメチルフェノ 一ルをそれぞれホルムアルデヒドと混合(モル比 $1: 1$ ) してアンモニアを触媒とした樹脂を合成し， $3,000^{\circ} \mathrm{C}$ までの熱処理を行なつて，これらの ESR を測定した 結果 ${ }^{55)}$ から, フェノールホルムアルデヒド樹脂炭にも やはり 2 成分があることを認めている。

以上のように, 種々の測定機器によつて求められた 石炭の物理的性質の特徵は, 石炭化度が増大寸るに従 つて，C 85 90\% 附近に一つの大きな転移点を有す るといらことである。すなわち, 硬度, 真比重, 内部 表面積, 浮選速度定数, 脂肪族 $\mathrm{CH}$ (赤外), ピーク 間ライン幅（ESR） などが，C 85 90\% 附近で著し く変化するといつた一つの特性を石炭が持つているこ とになり，注目されるところである。これと同様の性 質は他にマイクロストレングス，孔隙率，誘電摔など にも認められている。いずれにしても，石炭の物理的
性質としては，この附近で骨格構造単位の大きさの分 布が均一化されて, つぎの芳香族構造の発達が, 形成 されやすいよらな状態に整えられてくるものと推察さ れる。

\section{V. 石炭の化学的性質}

石炭を溶剂処理，酸化分解および水素化分解処理ま たはその他の处理をして, 石炭の化学構造を解明しよ らとする努力は，多くの研究者によつて進められてい るが，一方では石炭化学工業として利用面に欠くこと のできない性質, 条件を提供するものであるだけに, 生成物に対する分析機器の駆使による研究が, 各方面 にわたつて行なわれている。つぎに最近における研究 の動向についてみてみよう。

\section{1. 溶剂処理}

石炭を有機溶剂で処理して抽出物の検索を行ない， 石炭の構造, 性質を論じようとする最近の研究をみる と, 前述したように, ピリジン抽出あるいは石炭の熱 分解温度附近の比較的高温度で溶剂处理して多量の抽 出物を得る行き方と, 比較的温和な条件で抽出を行な ら行き方とがある。後者の方法については, 大内ら ${ }^{56)}$ が夕張炭のベンゼン抽出を行ない, 芳香族構造として クリセン，ピセンのようなジグザグカ夕型のものが存 在するといらことを明らかにしており，また同じく伊 牟田ら ${ }^{57}$ は, 液体クロマトグラフィーによる成分の同 定を行なつている。

また M. M. Roy ${ }^{58)}$ はピリジン抽出物のカラムク ロマト分離により, ナフタリン, フェナンスレンもし くはアントラセン型の $2 \sim 3$ 環の芳香族が存在するこ と,またフェノール性 $\mathrm{OH}$ 基, アルキル側鎖などの 存在を報告している。

溶剤処理は, 溶剤が石炭を構成する基本構造単位の 相互間の微細な間隙にまで浸透していき, 構造単位相 互間の結合の弛緩ないしは切断を引起すものと考えら れる。このために, 石炭は種々の大きさの単位体に切 断され，溶片中に分散されることになる。この場合， 溶凨の量が多いと石炭の膨潤を起すことになる。膨潤 現象の原因については馬場 ${ }^{59}$ によつて速度論的な考察 が加えられている。最近では，真田ら ${ }^{60)}{ }^{61)}$ が， M. L. Huggins の熱力学的高分子溶液理論を発展させる とともに, 石炭化度の異なる石炭をピリジン, ジメチ ルホルムアミド, 1.4 ジオキサン, ベンゼンなどによ る抽出を行なつた結果から, 平衡膨潤度（膨潤相中の 溶質の容積分率の逆数值）は C $85 \%$ 附近に転移点が あること, 溶剤の溶解度パラメーター 11 附近に極大 值があることなどを認めており (第 5 図)，石炭の凝 


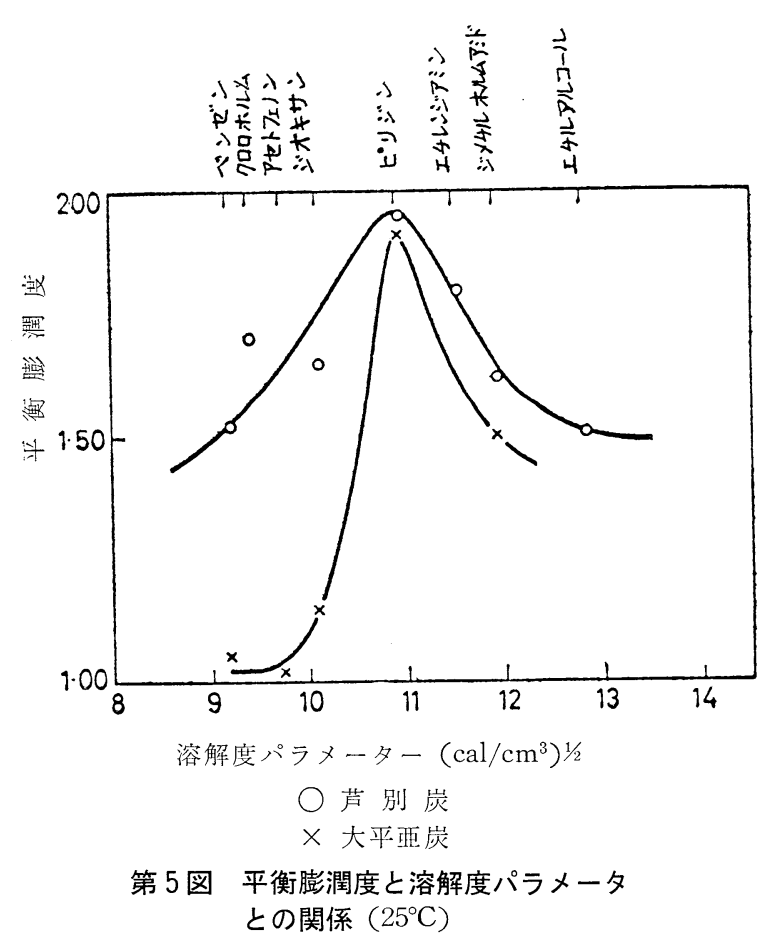

集エネルギー密度は $100 \mathrm{cal} / \mathrm{cc}$ ぐらいであると推定 している。また岡本ら ${ }^{62}$ は膨潤機構について述べてお り，中川ら ${ }^{63)}$ は膨潤炭製造に対する化学的検討を加兄 るために，三池炭に対してアントラセン油，ピッチ 油, コールタールなどの溶剤処理を行ない，生成油の ガスクロマトグラフィーによる成分の同定を行なつて いる。

以上のように，溶剂処理による石炭構造の究明に加 えて，膨潤化を行ない，これをタール系塗料あるいは バインダーとして使用する研究も実施されている。特 に注目されるのは，昭和39年九州に新しく九州工業技 術試験所が設立され，この方面の研究を推進しつつあ ることで，石炭に関する新しい研究機関が増加したこ とになり今後の発展が期待される。

\section{2. 酸化分解}

石炭の酸化分解，フミン酸に関する研究は，瀝青炭 に対してはすでに横川，武上ら ${ }^{64)}$ ，神谷 ${ }^{65)}$ ，また亜炭 に対しては樋口ら ${ }^{66)}$ の詳細な研究があるが, 酸化生成 物である再生フミン酸, ベンゼンカルボン酸などの有 機酸が，工業的にも有効に利用されることに関連し て，引続いて多くの報告がなされている。現在， R. S. Montogomery ら ${ }^{67}$ が加圧酸素酸化して得た有機酸 を処理した後, 質量分析, 赤外, 紫外吸収スペクトル などの各種分析機器を利用して確認した主なる芳香族
構造としては，ベンゼン，ナフタリン，フェナン スレン, ジフェニル, ターフェニルなどがあり， J. Entel ${ }^{68)}$ もほぼ同様の結果を得ている。一方, わが国において最近みられる研究には，次の上う なものがある。

湿式酸素酸化々硝酸酸化の研究は, 西田, 宮下 ら ${ }^{69}$ によつて継続中であるが，この両者の反応性 状, 特に反応速度とフミン酸生成の選択性につい て比較すると，かなりの相異があり，硝酸酸化の 方がよいことが認めら礼ている。一方，酸素酸化 の場合でも，水媒体に Mo，Wなどの金属塩さ 添加すると, フミン酸生成の選択性を増し, 硝酸 酸化に近ずけらることを示している。また赤外吸 収スペクトルによる $5.88 \mu\left(1,700 \mathrm{~cm}^{-1}\right)$ の吸収 がカルボキシル基によるものであること，吸光度 と化学的測定值との間には直線関係があることな どを認めている。同様に藤井ら ${ }^{47)}$ は $5.88 \mu$ にお ける吸収が，主としてカルボキシル基によるもの であることを示しているが，さらにいくつかの仮 定のもとに, 石炭化度が増大寸るに従つて, 酸化 除去された炭素の数が減少すること，すなわち石 炭のアルキル側鎖の長さが, 石炭化の進行とともに短 かくなる傾向があることなどを認めている。

本田, 山川 (5) $^{71}$ 怯, 亜炭から無煙炭に至る石炭 化度の異なる石炭をそれぞれ温度条件を変化させて空 気酸化し, 酸化炭の組成変化について検討している。 この結果から第 6 図のように，それぞれ直線にのるこ と, 直線の傾斜は水素の離脱に対する酸素附加の割合 を示すことなどを認めている。一方，重量変化と生成 ガスの重量法による定量から，水， $\mathrm{CO}_{2}, \mathrm{CO}$ および 石炭結合酸素量を求好々ともに，石炭から得られた フミン酸のイオン交換能についても，モデル物質，合 成イオン交換剤などと対比させて検討している。ま た, 泥炭, 亜炭, 酸化炭などからアルカリ水溶液によ りフミン酸を抽出する際に, 水溶性物質, 揮発性酸, $\mathrm{CO}_{2}$ などが副生されるが，これらが酸化炭およびフミ ン酸構造，性質に関連があることを示している。

一方，ルール炭の硝酸酸化を行なつた B. Jüttner $ら^{722}$ は，生成されたカルボン酸の種類と組成が，石炭 化度と密接な関係にあることを報告している。

その他, 長広, 有田ら ${ }^{73)}$ はゲルろ過法によると, 再 生フミン酸の分別がきわめて容易であること，船阪 ${ }^{74}$ らは酸化により生成されたカルボキシル基の分析法と しては，気一液クロマトグラフが適用しらることなど を示しており, 武上ら ${ }^{75}$ はつフミン酸の Adkins 触媒に 


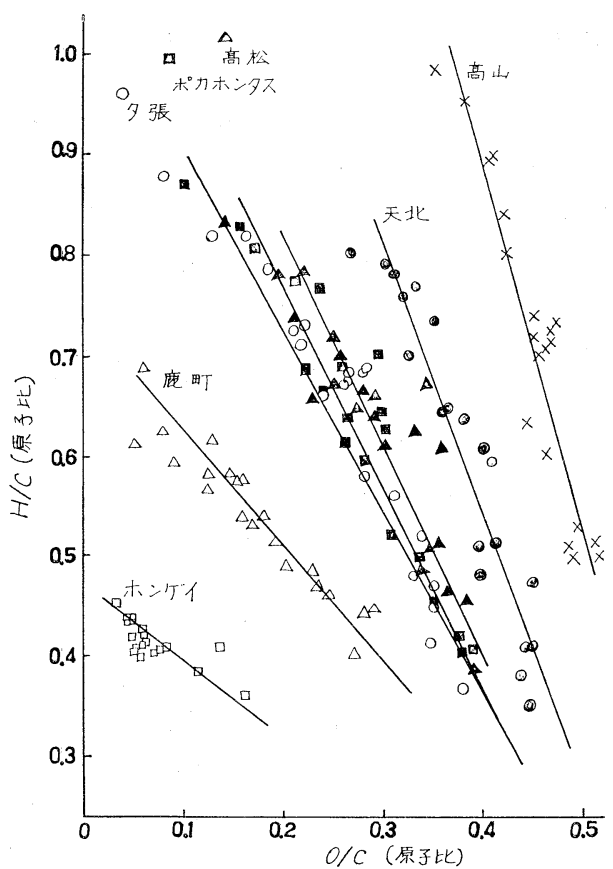

第 6 図 空気酸化炭の組成変化

よる水素化を行ない，エーテル型架橋についての知見 を与えている。

\section{3. 水素化分解}

石炭の水素化分解に関寸る研究は，その分解生成物 より純䊉物質を分離して, フェノール類, 芳香族炭化 水素などの合成化学原料の製造を目的とした工業化の ための基礎資料をうるために行なわれている。しかし 一方では，柽度の水素化分解莸行ない，その生成物の 解析から不炭の化学構造に関する知見を得るための一 つの大きな化学的手段ともなっている。従つて，酸化 分解とともに現在采でに数多くの研究が進められてい るが，最近みられる主なものについて述べることとす る。

坂部 ${ }^{76)}$ は, 加圧水素下における接触反応により, 石炭を化学原料その他の有用な製品とするための一連 の研究を行なつた。すなわち，連続陚験装置により三 池炭を原料として高圧液相水素化分解（反応圧力 300 atm）を行ない，その生成油として沸点 $300^{\circ} \mathrm{C}$ 以下の 中軽油より抽出分離して中性油とし，さらにこの中性 油分の接触水素化脱了ルキル反応 (反応圧力 $30 \mathrm{~atm}$ ) を組合せて行なうことによつて，石炭から芳香族ケミ カルズの製造試験を実施した。この場合の無水無灰基 の原料炭に対寸る生成物の収量は, 芳香族炭化水素類 $24.2 \%$ ，フェノール類 $9.1 \%$ ，アミン類 $3.3 \%$, 揮発
油など $7.0 \%$ ，ガス状炭化水素 $44.6 \%$ ，で，その他 に硫化水素 $1.0 \%$ ，アンモニア $0.3 \%$ が副生すると いつた総合的な結果が示されている。さらに，夕張 炭に対する軽度の水素化分解を行ない.77)，その生成物 を溶剤処理して，分子量測定，環分析などから化学粠 造について検討したが，この結果として，分子量は $300 \sim 1,500$ の籁囲にあること，構造単位体中の芳香 族骨格構造は平均して 3〜4 環のジグザグカタ型であ ることなどを示している。

芳香族骨格構造が夕張炭で 3 4 環程度であること は，ベンゼン抽出物による結果からも認められてお り, この他, 本田ら ${ }^{78)}$ が磁気係数, 武谷ら ${ }^{51}$ が NMR スペクトルからも認めているところである。一方ほぼ 同一石炭化度の外国炭については，一般にやや高い環 数が示されているが，I.G.C. Dryden ら ${ }^{79)}$ は，燃焼 熱および NMR 吸収スペクトルより，ほぼ日本炭と 同様の值を得ている。

高圧水素化分解に関する試験は, 武谷ら ${ }^{80)}$ も詳細な 研究を行なつているが，一方では石炭の化学構造解析 の立場からも系統的な研究を進めている。すなわち石 炭ペーストの一次水素化分解（初圧 $100 \mathrm{~kg} / \mathrm{cm}^{2}$ ) 生成

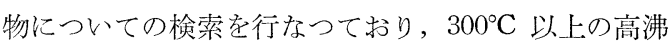
点留分について重水素ピリジンを溶媒とした MMR スペクトル分析より，各種結合様式の水素含有量およ び芳香族性 $f_{a}$ について検討した結果 ${ }^{811}$, 夕張炭につ いてみると, 反応温度 $400^{\circ} \mathrm{C}$ で, 反応時間 $1 \mathrm{hr}$ のと きは, $0 \mathrm{hr}$ よりも芳香族水素 $\left(\mathrm{H}_{a}\right)$ が多く, 芳香族 側鎖の $\alpha$ 位飽和脂肪族水素 $\left(\mathrm{H}_{\alpha}\right)$ および芳香族側鎖 の $\alpha$ 位以外の飽和脂肪族水素 $\left(\mathrm{H}_{0}\right)$ が少ないこと， $450^{\circ} \mathrm{C}$ で洼反応時間による差異がないこと， $f_{a}$ は $0.66 \sim 0.72, \mathrm{H}_{0} / \mathrm{H}_{\alpha}$ は区応条件比よらず $1.3 \sim 1.4$ で ほぼ一定であることなどを認めている。また，高圧示 差熱分析装置を陚作して，石炭の水素化分解反応阔関 する熱的研究80)も行なつている。

一方, 藤井 ${ }^{82}$ も 夕張炭の高圧水素化分解（初圧 100 $\left.\mathrm{kg} / \mathrm{cm}^{2}\right)$ を行なつて招只, 分解生成物を赤外吸収スペ クトル分析した結果，反応温度が $375^{\circ} \mathrm{C}$ と低温。場 合には，全水素，脂肪族水素ともに増加寸るが，比 較的高温の $425^{\circ} \mathrm{C}$ の場合には，反応の初期段階で両 者とも急激に増加するが，反応が進むと逆減少する ことを耖めている。この反応は, 前者が芳香族環の飽 和反応，および低級炭化水素の脱離を伴なわない $\mathrm{C}$ $\mathrm{C}$ 結合の水素化切断反応であり, 寸なわち解重合反応 であるのに刘して，後者はアルキル基の脱離反态（ガ 不状低級炭化水素として脱離）であると推定してい 
る。またこのような見解から水素化分解によつて石 炭の化学構造を論ずる際には, 反応温度が $375^{\circ} \mathrm{C}$ 以下 が望ましいことを結論している。

4. その他の処理

石炭の化学構造解析のための知見を得るために, 最 近行なわれたその他の化学的処理には, 解重合, アル カリ分解，電解還元などがある。

武谷ら ${ }^{833}$ は， $100^{\circ} \mathrm{C}$ 以下で三弗化硼素一フェノー ルによる比較的温和な条件下の解重合を行ない, 反応 温度, 時間, 触媒などの効果について検討を加えてい る。夕張炭の沃化水素酸と水素による解重合を行な い, ベンゼンおよびピリジン抽出物の NMR スペク トル, 赤外吸収スペクトルによる構造解析を行なつた ところ, 縮合環数が 4 環であることを認めている。こ の三弗化研素とフェノールによる解重合に関寸万研究 は L. A. Heredy $5^{84)}$ も行なつている。

一方, 伊牟田, 山下 $5^{85}$ は, 夕張炭を浱硫酸のフェ ノール溶液中に繋濁させて, 石炭中のメチレン結合を 開裂させる低温接触解重合を行ない，その生成物を液 体クロマトグラフで分離して赤外, 紫外吸収スペクト ルによる成分検索をした結果, 現在までにベンゼン可 溶部に対して，パラフインおよび脂環化合物 $8.2 \%$ ， ベンゼンおよびナフタリンアルキル誘導体 $4.2 \%$, フ ェナントレンアルキル誘導体 $1.5 \%$, クリセン誘導体 $0.43 \%$, ジメチルピセン $0.58 \%$ などが存在すること を確認している。またこの際の触媒としては, やはり 三弗化研素が有効であることを示している。

常本ら ${ }^{86}$ は, 石炭をアルカリ溶融分解して再生フミ ン酸を得る際に, 超音波を作用させる試験を試みたと ころ, 解重合が促進されること, 反応温度が高いほど 効果があることなどを明らかにしている。

一方, 武谷ら ${ }^{877}$ は, 褐炭㧍よびリグニンを $\mathrm{NaOH}$ 水溶液に賏濁させて電解還元処理を行ない, 分解效果 および生成物の検討を進めている。

以上の上うに, 石炭の化学的性質についても多方面 にわたつて研究が進められており, 石炭の基本構造を 形成する芳香族構造の確認が行なわれている。また夕 張炭に対する研究結果から, 芳香族骨格構造の平均の 環数が 3〜4 環程度と外国炭よりも低いことが認めら れていることは, 日本炭が外国炭よりも芳香族構造部 分が少なく, 脂肪族構造部分をより多く含んでいるこ とになる。一方, 芳香族性 $f_{a}$ の值も $0.66 \sim 0.72$ と 低い值を示している。石炭化に関連するこの芳香族構 造と脂肪族構造との相対的な関係は, 今後ますます追 求されると思うが, 石炭の基本構造あるいは構造模型
などの解析には，これらの化学的性質に加え下，物理 的性質その他の性質を加味して, 総合的に考察し発 展させていかなければならない多くの問題を含んでい る。

\section{VI. 石炭の熱分解，炭化}

石炭の熱分解に関する研究は, 粘結性, 许留など上 関連させて幅広く検討されている分野であるが，最近 では石炭本質の熱分解機構を明らかにするために, 生 成物の検索汇加えて, 示差熱分析装置, 高真空熱分解 装置, 超音波装置など各種の機器を利用した研究が進 められている。

さらに，もつとも注目されるのは，わが国における 製鉄用原料炭対策，不炭産業刘策の一環加，国内炭 の利用とコークス炉の生隆性向上を目的として，一般 炭あるいは非粘結炭, 弱粘結炭を主原料と寸るコ一ク スを製造しょうと寸る予熱炭装入法, 成型炭装入法, 加熱成型乾留法などの開発研究が実施されていること である。

従つてこれに関連した研究として, 石炭の予熱処理 効果の解明が組織的に進められている。またバインダ 一の添加あるいはバインダーなしにブリケット化する 研究が, 大気污染対策としての無煙燃料製造の立場か ら，北開試および石炭技研において精力的に進められ ている。さらに, これは活性炭製造のための造粒対策 にもつながる問題でもあり, 現在, 資源技術試験所に おいて $\mathrm{SO}_{2}$ 吸着のための球形新活炭製造の開発研究 が着々と進められている。この他に乾留, 炭化に伴 ならガス, コークスの性状, 反応性, 強度などの物 性の変化の検討など利用面に直結した問題など種々多 方面にわたる試験研究がある。しかしながら，コーク ス関係についてはコークス部会のほうで詳しく述べら れると思うので, ここでは割愛することとし, 最近に みられる熱分解関係の研究についてのみ述べることに する。

石炭の樊分解反応は, 石炭中にある低分子物を溶剂 抽出して得られる残渣炭について研究するか, あるい は熱分解生成物である発生ガスを分析するかのいずれ かによる考察が進められている。

武谷, 工藤ら ${ }^{887}$ は, 赤平炭を用い水素, アルゴン, 酸素などの各種雲囲気下に熱分解を行ない, 各温度に お汀炭質残渣の活性含酸素基 $(\mathrm{OH}$ 基, $\mathrm{CO}$ 基, $\mathrm{CO}$ $\mathrm{OH}$ 基など) について検討した結果, 熱分解温度上昇 に伴なら $\mathrm{OH}$ 基の離脱に対寸る雲囲気の影響は, 酸 媇, 水素, アルゴンの順であるこ上，またこ机らの含 酸素基は, 温度上昇とともに次第に減少す万ことなど 


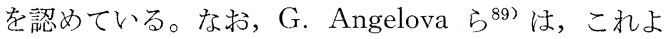
り石炭化度の高い粘結炭クラスでは $400^{\circ} \mathrm{C}$ 附近の 軟 化領域で $\mathrm{CO}$ 基, $\mathrm{OH}$ 基に極大值が存在することを 認めている。

熱分解の初期には, これらの含酸素基はまず分解さ れ $\mathrm{H}_{2} \mathrm{O}$ をはじめとして $\mathrm{CO}, \mathrm{CO}_{2}$ を発生するが, さらに熱分解が進むと，水素およびメタンなどの炭化 水素が放出されて, 結果的に芳香族環の大きさが増加 する方向に向らことになる。

この熱分解機構について大内ら ${ }^{900}$ は, 標準物質とし てベークライト系樹脂を用いて質量分析により熱分解 ガスの分析を行ない，脱ガス過程と芳香族環の発達過 程に関する興味ある結果を示しているが，続いて夕張 炭についても, やや複雑ではあるがよく類似した分解 過程を辿ることを認めている。すなわち第7図のよう に, $400^{\circ} \mathrm{C}$ では $\mathrm{COOH}$ 基の分解による $\mathrm{CO}_{2}$ を発生 し，400 500 ${ }^{\circ} \mathrm{C}$ では多量の炭化水素ガスの発生がみ られるが，これは石炭中に存在していた長いアルキル 側鎖が分解したものと考えられること， $500 \sim 700^{\circ} \mathrm{C}$ では脱水により生じたエーテル結合の再分解による $\mathrm{CO}, \mathrm{CO}_{2}$ の発生, ナフテン環の脱水素などが起り, 次第に芳香族環の拡大に進むものと思われることなど を示している。一方, 玉杵ら ${ }^{91}$ は, 熱分解法によるガ スクロマトグラフにより分解ガス中のメタンについて 検討している。これによると C 85 87\% に極大值が

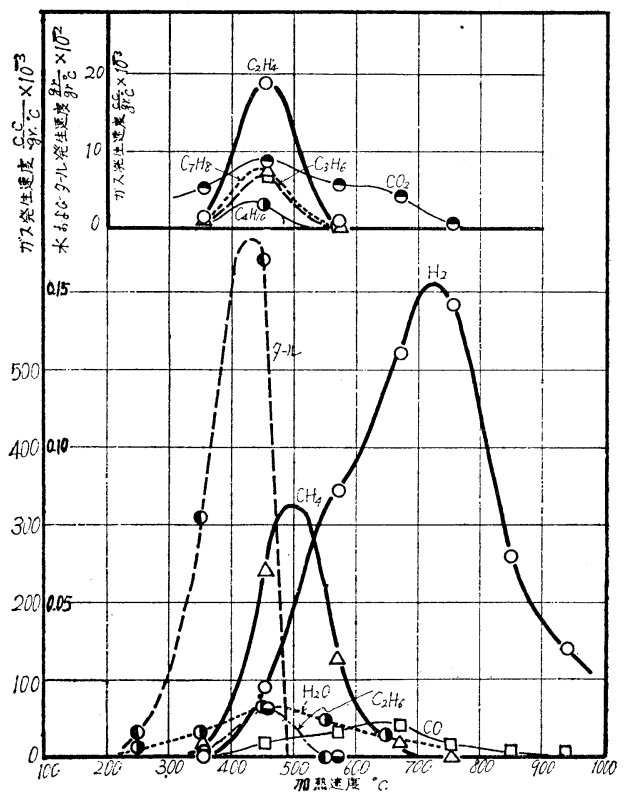

第 7 図 加熱温度と分解ガスとの関係 (夕張炭)
存在することを認め，石炭化度と密接な関係があるこ とから，この方法が石炭類の分類にも利用しらること を示している。

川名ら ${ }^{92}$ は, 熱天秤抢よび示差熱分析を用いて石炭 の熱分解機構について研究したが，この結果による と, 粘結炭の示差熱分析曲線には, 分解による $2 つ の$ 吸熱ピークと $2 つ の$ 重合，環化架橋のための発熱によ る急激な立ち上りが現われること，しかも第 1 番目の 発熱は，石炭の粘結性にとつてなくてはならないもの であることなどを明らかにした。同様に吉村ら ${ }^{93}$ は， 膨張の大きい石炭に詨してアルミナ, シリカゲル, 活 性炭，コークスなどの不活性物質を添加した場合の示 差熱分析に掠よぼす影響について検討するとともに， 夕張炭に酸化鉄を加えた熱分解を行ない，石炭中のメ チレン基が酸化されてアルコールおよびケトンが生ず ることなどを明らかにしている。また最近, H. Luther $ら^{94)}$ も, 示差熱分析により石炭化度の差異にみられる 吸熱, 発熱現象の特徴についてのべている。

一方, B. Sun, H. C. Howard $~^{95}$ は, 高真空下 (10 $10^{-4} \mathrm{mmHg}$ 以下) に扔ける熱分解で比較的容易に 低分子物をとり出しらることを示したが，藤井ら ${ }^{96)}$ は この分子蒸留装置の一部を改良して, 石炭化度との関 係について検討した結果, 留出物収率と試料の水素含 有量とは直線関係があること，またガス収率と試料の 酸素量とも直線関係が成立することを認めている。

石炭の粘結性およびュークス化性におよぼす熱処理

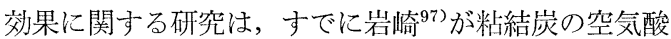
化による配合効果を認めているが，現在，石炭技研， 早大，資源試が中心となつて総合的なグループ研究を

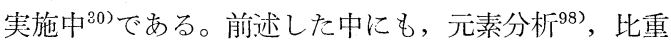

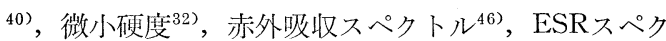

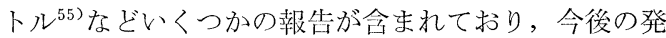
展が期街されている。

予熱あるいは乾燥装入効果は, 装入密度の増大, 加 熱速度の増大に上る生産性の増強と乾留時間の短縮が もたらされるといら利点があることは，すでに知られ ているところであるが，このほかに予熱することによ つて石炭の性状になんらかの変化がもたらされている はずであるが，これらははたしてなんであろらか。決 定的な効果は脱水によつてもたらされる影響だけであ ろらか。この点に対する解答は, いずれ前記グループ 研究の結果として示されるものと思う。

一方，予熱炭の性状変化について吉田ら ${ }^{99}$ が行なつ た結果によると， $500^{\circ} \mathrm{C}$ までの予熱炭ら恒湿試料水分 の変化は $400^{\circ} \mathrm{C}$ に極小值が認められること,この傾 
向は石炭化度の低いものほど著しいことなどが特に目 立つた性状変化であつた。しかしピリジン，クロロホ ルムなどによる溶威抽出量の変化は，一般に粘絬炭で は軟化温度附近で増加するといわれているが，この奏 験ではかえつて減少を示し一定の傾问が認められなか つた。また流動度は予熱温度とともに次第に低下寸る が, 軟化, 最高流動, 固化などの各温度の変化も, や はり炭種によつて必ずしも一定の傾向を示さなかつ た。一方, 示差熱分析では, 予熱温度の上昇とともに 吸熱，発熱のピークが浅くなり，曲線がなだらかにな るといつた一定の傾向を示すことが認动られる。これ は表面の酸化に起因寸る流動度の低下とも考えられる ことを強調している。

いずれにしても， $400^{\circ} \mathrm{C}$ 前後の軟化領域における変 化が若干認められることはとも角として，少なくとも $250^{\circ} \mathrm{C}$ 前後の予熱効果が，はたして水分の問題以外に 石炭性状にどの程度までの変化を与えているのか，今 後の問題として大いに注目されるところである。

原料炭の予熱あるいは乾燥装入法は, わが国ではも とより，諸外国においてもフランスを始めとしてアメ リカ, イギリス, ドイッ, ソ連さらに濠州など前述し た経済性の故に盛んに試験研究が進められている。一 部ではすでに実操業にとり入れているところもあり， 今後も予熱装置およびパイプ装入の開発などとともに ますます発展するものと考えられるが，ここではその 詳細は省略する。

最後に, 炭化ならびに黒鉛化の問題があるが，これ については, すでに大内 ${ }^{100)}$ が石炭の熱分解と同様に 前記のベークライト系樹脂および石炭化度の異なる石 炭を使用して，それぞれ $2,000^{\circ} \mathrm{C}$ までの熱処理を行 ない, 磁気係数, 比重, 電気抵抗, X線などによる測 定結果を比較検討し，黒鉛化性は C 88\% 附近に極大 值があること，良黒鉛化性に必要な条件は $\mathrm{CH}_{3}$ 基が 多量にあることなどを認めている。また江木 ${ }^{101)}$ は $1,000^{\circ} \mathrm{C}$ までの熱理を行ないX線回析をした結果か ら, 結晶子の層の大きさおよび層の重なりの分布が発 達すること, 面間隔 $4 \sim 5 \AA$ の $\gamma$ バンドの強度が C 85\% 附近で極大值をとることなどを認めている。

最近では本田ら ${ }^{1022}{ }^{103)}$ が赤平弱粘結炭とイットマン 強粘結炭とを $3,000^{\circ} \mathrm{C}$ まで熱処理して, X線回析, ESR スペクトル, ホール係数, 磁気係数おょび硬 度, 熱膨張率, 熱伝導率など種々の物性值を求め, 前 者が難黒鉛化性カーボンに, 後者が良黒鉛化性カーボ ンに属すること, また処理温度の増大とともに熱伝導 率が増加することなどを铝めている。すなわち，一例

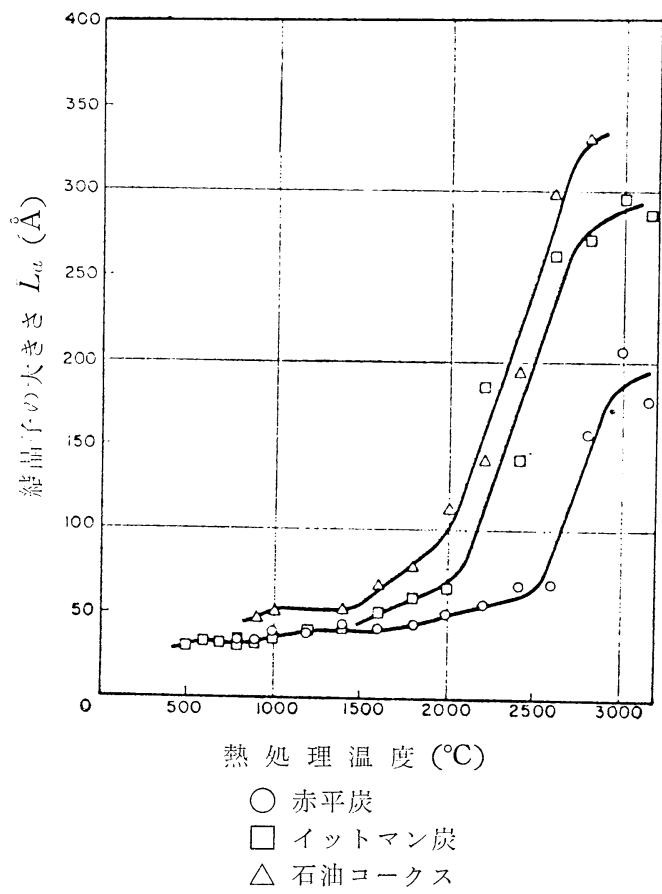

第 8 図 熱処理温度と結晶子の大きさ $\boldsymbol{L}_{a}$ との関係

をあげると符 8 図のように， $a$ 軸方向の結晶子の大き さの成長に炭種による差異があることが認められてい る。さらに石炭化度の異なる石炭を $2,000^{\circ} \mathrm{C}$ で熱 処理して ESR スペクトル測定 ${ }^{104)}$ 幅, スピン濃度, $g$ 值などの特性值について榆討した 結果, $700 \sim 900^{\circ} \mathrm{C}, 1,200 \sim 2,000^{\circ} \mathrm{C}$ 附近に転移点が あることを認めている。

以上の上うに, 石炭の高温に抒ける諸物性が着々と 明らかにされつつ岕るとは，石炭のカーボン材への 利用開発につながるもので, その機械的強度が大であ るといった性質を活用し，あるいは低いとされている 電気伝導度の増加などを図るために, 石炭の熱分解に 関する研究とともに，今後末すます発展させていかな ければならない分野である。

\section{VII. 石炭科学部会について}

以上, わが国における不炭科学の研究動向につい て，その主要なものについてのみ述べてきたが，これ らの大部分は, 燃料協会の石炭科学部会が主催する石 炭科学会議において発表されたものである。

石炭科学部会は, 然料協会の一部会として構成され ており，前身である石炭組織研究会の第 8 年会 (1964 年 4 月開催) の麿上多くの不炭研究者が集つ下自由㣙 議できる共通の掦を持つことの必要性が痛感され1964 年 5 月に設立されたもので, 第 1 回石炭科学会議は 
1964年11月13日開催され現在に至つている。

石炭は, 一人の研究者汃一つの研究手段を用いて, その位置ゔけを行なおうとしても, それは石炭の化学 構造なり，性状などのある一面のみをみているにすぎ ないといつた複雑な構造を有する有機質の固体であ る。従つて, その本質も充分に理解されず, 多くの末 解決な問題を残すことになる。このために, 地球科学 的分野および物理化学的分野など石炭に関連するあら ゆる専門分野の研究者が集つて, 相互の研究成果や知 識を交流し合い，討議し合つて，お互の境界領域に残 されている問題, 末解決の問題を総合的に検討する必 要がある。この目的のために, 石炭科学部会が中心と なつて, 日本炭の化学構造, 基礎的性質に対する総合 的な結論を導き出寸詂論の場としての石炭科学会議を 持ち, 石炭科学の向上, 発展を図らうとしている。

現在, 燃料協会会員のらち石炭科学部会所属の会員 は, 140 名程度であるが, 名誉委員 16 名, 在京委員 16 名, 地方委員として北海道地区に 6 名, 近畿地区に 5 名, 九州地区に 8 名がおり, 各委員が相互に連絡をと りながら, 在京委員が主になつて運営されている。昨 年11月11，12日に日本化学会と共催のもとに開催され た第 3 回石炭科学会議には, 日本石炭協会, 石炭技 研, 日本タール協会, 日本コ一クス協会, 鉄鋼連盟の 後援を得て, 全国よりの出席者 110 名, 講演件数 11 件, 特別講演 1 件ときわめて盛大な会議であつた。そ の内容はプレプリントを作成し前以つて出席者に送附 しておき, 講演20分, 討論40分といつた討諭を主とす る運営法で, 部会の目的にそつて着々とその成果を挙 げつつある現状にある。

この機会に, 石炭科学部会の主旨に賛同し, 石炭科 学の発展に深い関心を持つ方々の多数の参加を切望す る次第である。

\section{VIII. 結言}

日本炭の化学構造, 物理化学的性質, 特徵を明確に するために, 最近長足の進歩をとげつつある分析, 測 定機器の利用により, 石炭科学に関寸る種々の知見が 得られている。わが国に豊富に埋蔵されている天与の 地下資源である石炭を, より有效に利用し活用するた めに，われわれ石炭関係者は，址質，採炭，選炭，燃 焼, 乾留あるいは石炭化学などあらゆる分野にわたつ て，もら一度新しい視野に立つた基礎的考察を総合的 に加える必要がある。たとえば，前述したよらに C 85 〜 90\%において認められる転移点についての徹底的解 明は, 石炭の化学構造夌も含めて, その性状を左右す る重要な問題であるといわなければならない。
このためには，多様性に富むそれぞれの性質あるい は結果を相互に検討し合い, 地質から物理化学, 利用 に至るまで一貫性を持たせて相互間の結びつきをより 強固にする必要がある。従つて, 同一試料による研究 の必要性, 各研究機関が所有する各種機器の使用によ る共同研究の必要性, さらには各分野における研究者 の知識の交換と総合的検討の必要性, あるいはこれら の意慾に対する関係機関の研究者への理解など種々重 要な問題を含んでいる。

現在, 前述したように石炭の熱処理効果解明のため に, 資源技術試験所, 早稲田大学, 石炭技術研究所の 間で，同一試料によるグループ研究が進められている のも，その一つの行き方であるといえよう。

每年一回開催される石炭科学会議もまた, 以上の目 的にそうものである。これらの研究活動を通じて, 石 炭科学の総合的研究開発に努力し, 日本炭の特性を生 かした利用開発の確立を図万ならば, 石炭科学の今後 の発展は注目すべきものがあると信ずる。

\section{文 献}

1）黑川真武, 馬場有政, 本田英昌, 大内公耳, 石炭 - 石炭化学, 日刊工業 (1963)

2) 亘理俊次, 第 3 回石炭科学会議, 2 3 (1966)

3) 徳永重元, 燃協誌 44, 792 (1965); 第 3 回石炭 科学会議 1 ～(1966)

4) 佳々保雄, 第 3 回石炭科学会議, 1 3 (1966)

5) 木村英雄, 然協誌, 39, 803 (1960)

6）高橋良平，燃協誌，39，624 (1960)

7) H. J. Kisch and G. H. Taylor, Econ. Geol., 61, 343 (1966)

8) D. Chandra, Fuel, 44, 171 (1965)

9）塚島寬，加藤勉，富山大工記要，11，41 (1960); 燃協誌，44，838 (1965)

10) 舟阪渡, 横川親雄, 石炭化学, 共立出版, 20(1964)

11）岡野宽，相原安津夫，燃協誌，44，774 (1965)

12) 燃料協会石炭組織研究会, 燃協誌, 36, 207 (1957)；37, 597 (1958)

13）木村英雄，選炭，9，28（1959）

14) International Handbook of Coal Petrography (1963); M. Th. Mackowsky, Brennstoff-Chem., 47, 183 (1966)

15）木村英雄，資源試報告第55号（1962）

16）佐々木実，北海道釧路炭田調查，（未発表）

17）高橋良平，鉱山地質，9，23 (1959)

18）柴岡道夫，道工試報告第154号（1958）

19）中柳靖夫，燃協誌，43，808 (1964) 
20）岩崎高雄，然協誌，37，242(1958)

21）杉村秀彦，紫波正史，石炭技研検鄙会（1966）

22) 丸山敏雄, 燃協誌, 44, 783 (1965); 第 3 回石炭 科学会議, $2 \sim 2$ (1966)

23）高橋良平，竹下健次郎，常本武，燃協誌，44, 815 (1965); 第 3 回石炭科学会議, $1 \sim 2$ (1966)

24）鳥飼直親, 加戸達雄, 燃協誌, 44, 473 (1965)

25）木村英雄, 白石稔, 日化会第18，19年会 (1965), (1966)

26) C. Kröger, Brennstoff-Chem., 45, 9, 170(1964); 46, 280 (1965)

27) P. H. Given, M. E. Peover and W. F. Wyss, Fuel, 44, 425 (1965)

28) M. M. Roy, Econ. Geol., 60, 1213, 1404(1965)

29) K. Kötter, Brennstoff-Chem., 40, 305 (1959)

30）本田英昌，藤井修冶，泉野広，燃協誌， 45, 185 (1966)

31）向井滋，若松貴英，石川恒夫，日本鉣業会誌， 82, 25 (1966)

32）紫波正史, 杉村秀彦, 真田雄三, 第 3 回石炭科学 会議, 2〜4 (1966)

33) H. Honda and Y. Sanada, Fuel, 35, 451 (1956); 36, 403 (1957)

34) D. W. van Krevelen, Caol, Elsevier, Amsterdam (1961); Brennstoff-Chem., 34, 167(1953)

35) 本間寅二郎, 山本満, 岩田博行, 増田薰, 第 3 回 石炭科学会議, 2〜5 (1966)

36) J. A. Dulhunty and R. E. Penrose, Fuel, 30, 109 (1951)

「33, 331 (1954)

37) P. Zwietering and D. W. van Krevelen, Fuel,

38) H. Honda and K. Ouchi, Fuel, 36, 159 (1957)

39）太刀川正一郎，資源試報第41号（1958）

40) 藤井修冶, 戸叶浩敬, 新畑俊治, 燃協誌, 45, 434 (1966); 第 3 回石炭科学会議 1 1 (1966)

41) D. Chandra, Econ. Geol., 60, 1041 (1965)

42) R. B. Anderson, J. Bayer and L. J. E. Hofer, Fuel, 44, 443 (1965)

$\lceil 453$ (1965)

43) P. L. Walker, Jr and K. A. Kini, Fuel, 44,

44）高宮信夫，石炭技研検討会（1956）

45）今泉常正, 井上外志雄, 梄原常栄, 燃協誌, 44, 830 (1965)

46) 武谷愿, 伊藤光臣, 牧野和夫, 横山晋, 北大工学 部報告第35号 (1964)

47）藤井修治，燃拹誌，43，821 (1964)

48) R. A. Friedel and J. A. Queiser, Anal. Chem.,
28, 22 (1956)

49) G. Bergmann, G. Huck, J. Karweil und H. Luther, Brennstoff-Chem., 38, 193 (1957)

50) R. A. Friedel, J. Chem. Phys., 31, 280 (1959)

51 ) 武谷愿, 伊藤光臣, 鉿木章, 横山晋, 然協誌, 43, 837 (1964)

52）金井弘，鈴木章，伊藤光臣，武谷愿，第 3 回石浆 科学会議, $2 \sim 6$ (1966)

53) J. Uebersfeld, A. Etinne and J. Combrisson, Nature, 174, 614 (1954)

54) Y. Yokozawa, I. Miyashita, M. Kugo and K. Higashi, Bull. Chem. Soc. Japan, 28, 536 (1955)

55）豊田貞治, 菅原幸子, 本田英昌, 第 3 回石炭科学 会議 1-4 (1966)；日化会第19年会（1966）

56) K. Ouchi and K. Imuta, Fuel, 42, 445 (1963)

57）伊牟田和敏，山下安正，日化会第19年会（1966）

58) M. M. Roy, Brennstoff-Chem., 47, 65 (1966)

59）馬場有政，資源試報告第27号（1954）

60）真田雄三，資源試報告第60号（1965）

61) Y. Sanada and H. Honda, Fuel, 45, 295(1966); 45 (1966) 印刷中

62) 岡本正弘，植田寿憲，燃協誌，44，806 (1965)

63）中川雅直, 山田泰弘, 日化会第19年会 (1966)

64）横川親雄, 渡部良久, 梶山茂, 武上善信, 錦織彰 工化，60，1030(1957); 燃協誌，39，590(1960); 40, 38 (1961)；42, 176 (1963)

65）神谷佳男, 工化，61，197(1958)，62，106(1959)

66). 樋口耕三，燃研報告第67号 (1952)

67) R. S. Montogomery and E. D. Holly, Fuel, 36, 63, 493 (1957)

68) J. Entel, J. Am. Chem. Soc., 77, 611 (1955)

69）西田清二, 碇屋道雄, 加藤信行, 宮下功, 燃協誌 44, 797 (1957)

70）本田英昌, 山川敏雄, 工化， 61，717（1958); 70 , 投稿中

71）山川敏雄, 工化，66, 357 (1963); 日化会第18, 19年会 (1965) (1966)

「46, 277 (1965)

72) B. Jüttner und H. Bertiling, Brennstoff-Chem.,

73) 長広洋子, 有田静览, 竹下健次郎, 日化会第19年 会 (1966)

「247 (1963)

74）舟阪渡, 小㞻次雄, 木本実美, 分祈化学, 12,

75) Y. Takegaimi, S. Kajiyama and C. Yokokawa, Fuel, 42, 291 (1963)

76) 坂部孜, 左雨六郎, 堀江典郎, 高橋至朗, 小楖良 
明，神林美男，資源試報告第66号（1966）

77）坂部孜，資源試報告第49号（1961）

78）本田英昌，大内公耳，資源試報告第 1 号 (1952)

79) I. G.C. Dryden, Fuel, 37, 444 (1958); 40, 433 (1961)

80) 武谷愿, 不井忠雄, 伊藤光臣, 久郷昌夫, 林茂, 前河涌典, 真壁正孝, 牧野和夫, 山口義見, 横山 晋, 長井弘, 赤間恶, 小池茂, 広田和一, 燃協誌 41，466 (1962); 北大工学部報告第35号（1964）

81）武谷愿, 石井忠雄, 横山晋, 真壁正孝, 日化会第 19年会 (1966)

82）藤井修冶，燃協誌，41，684（1962)； 43， 181

83）小川徳人, 牧野和夫, 石井忠雄, 武谷愿, 日化会 第19年会 (1966)

84) L. A. Herédy, A. E. Kostyo and M. B. Neuworth, Fuel, 44, 125 (1965)

85）伊牟田和敏, 山下安正, 大内公耳, 田中秀夫, 燃 協誌，44，582（1965）

86）常本武，有田静児，竹下健次郎，日化会第19年会

87) 武谷愿, 石井忠雄, 伊藤博徳, 永山政一, 畑中耕 一，日化会第18年会 (1965)

88）武谷愿, 石井忠雄, 牧野和夫, 工藤一至, 日化 会第18年会 (1965)

89) G. Angelova and L. Lazarov, Brennstoff-Chem., 46, $204(1965)$
90) K. Ouchi and H. Honda, Fuel, 38, 429(1959) 然協誌，40，845 (1961)

「年会 (1965)

91) 王杵滋富, 益子洋一郎, 本田英昌, 日化会第18

92) 川名善男, 牧野光男, 燃協誌, 43, 849 (1964)

93) 吉村太, 光井信二, 三谷忠由, 燃協誌, 44, 575 (1965); 45, 191 (1966)

94) H. Luther, W. Eisenhut und O. Abel, Brennstoff-Chem,, 47, 258 (1966)

95) B. Sun, C. H. Ruof and H. C. Howard, Fuel, 37, 299 (1958)

96) 藤井修冶, 新村正明, 三羽隆史, 日化会第 19 年

97）岩崎高雄, コークスの研究, 日刊工業, No.4, 281 (1953)

98）杉村秀彦，大沢祥拡，畑見正男，佐藤春三，本 田英昌, 燃協誌, 45, 618 (1966)

99) 吉田雄次, 第 3 回石炭科学会議 $1 \sim 6$ (1966)

100）大内公耳，資源試報告第31号（1955）

101）江木弘三，資源試報告第57号（1962）

102) H. Honda, K. Egi, S. Toyoda, Y. Sanada and T. Furuta, Carbon, 1, 155 (1964)

103) H. Honda, Y. Sanada, and T. Furuta, Carbon, 3, 421 (1966)

104) S. Toyoda and H. Honda, Carbon, 3, 527 (1966)

\title{
Trend of Research on Coal Science
}

\author{
by Hidemasa Honda and Hideo Kimura
}

(Resources Research Institute)

SYNOPSIS : - The petrographical constituents, the physical and the chemical properties of Japanese coal are different from those of foreign coals. Therefore, it is necessary to establish the all round knowledge as to the characteristics of Japanese coal.

At present, the research on coal science in this country tends toward the fundamental research by using the all kinds of analytical method, such as N.M.R.-, E.S.R.-, Infrared- and Mass-spectrometer etc., and the applied fundamental research manufacturing the humic acids, tar enamels, briquette coke for blast furnace use, smokeless fuel, activated carbon and artificial graphite etc. from Japanese coal only.

Particularly, it is expected to clarify the characteristics of Japanese coal as follows ; 
1) physical and chemical structures of coal

2) construction of critical points recognized at carbon content $85 \sim 90 \%$ (d.a.f.)

3) properties of heat treated coal in the early stage of carbonization

4) relation between aromatic $\mathrm{H}$ content and aliphatic $\mathrm{H}$ content in connection with coal rank

5) difference between Japanese coal and foreign coal

It is moreover requested to cultivate the new utilization technique fitted in the Japanese coal.

For instance, the research on physical and chemical properties of heat treated coal in the early stage of carbonization is now progressing in the cooperation of Resources Research Institute, Waseda University and Coal Mining Research Centre by using the same sample prepared carefully for this object.

On the other hand, the Division of Coal Scieace installed in the Fuel Society of Japan is now promoting the development of research on coal science, and held the 3rd conference of coal science for one of this purpose in Tokyo on Nov. 11 12, 1966.

The 4 th conference of coal science will be held at Fukuoka and Kita-Kyushu city in this year. 